\title{
KEADILAN HUKUM JEREMY BENTHAM DAN RELEVANSINYA BAGI PRAKTIK HUKUM KONTEMPORER
}

\author{
Frederikus Fios \\ Jurusan Psikologi, Faculty of Humanities, BINUS University \\ Jln. Kemanggisan Ilir III No. 45, Kemanggisan Palmerah, Jakarta Barat 11480 \\ fios2005@yahoo.com
}

\begin{abstract}
Fair punishment for a condemned has been long debated in the universe of discourse of law and global politics. The debate on the philosophical level was no less lively. Many schools of thought philosophy question, investigate, reflect and assess systematically the ideal model for the subject just punishment in violation of the law. One of the interesting and urgent legal thought Jeremy Bentham, a British philosopher renowned trying to provide a solution in the middle of the debate was the doctrine or theory of utilitarianism. The core idea is that the fair punishment should be a concern for happiness of a condemned itself, and not just for revenge. Bentham thought has relevance in several dimensions such as dimensions of humanism, moral and utility.
\end{abstract}

Keywords: justice, law, contemporary, ethics, utilitarianism

\begin{abstract}
ABSTRAK
Hukuman yang adil bagi seorang terhukum telah menjadi polemik panjang dalam jagad wacana hukum dan politik global. Perdebatan di tingkat filosofis pun tak kalah semarak. Banyak aliran pemikiran filsafat yang mempersoalkan, menyelidiki, merefleksikan dan mengkaji secara sistematis model ideal hukuman yang adil bagi subjek yang melanggar hukum. Salah satu yang menarik dan urgen yakni pemikiran hukum Jeremy Bentham, seorang filsuf ternama Inggris yang coba memberikan solusi di tengah perdebatan itu dengan ajaran atau teori utilitarisme. Inti pemikiran ini yakni bahwa hukuman yang adil harus memerhatikan kebaikan atau kebahagiaan seorang terhukum itu sendiri, dan bukan sekadar untuk balas dendam. Pemikiran Bentham memiliki relevansi dalam beberapa dimensi antara lain dimensi humanisme, dimensi moral, dan dimensi utilitas.
\end{abstract}

Kata kunci: keadilan, hukum, kontemporer, etika, utilitarisme 


\section{PENDAHULUAN}

Kosakata hukum memiliki banyak arti dan makna. Multitafsir dan multi-interpretasi hadir mewarnai konsepsi tentang hukum. Secara praktis, hukum sering dimaknai sebagai seperangkat kaidah yang dirancang oleh penguasa (otoritas) yang bertujuan tujuan untuk mengatur interaksi manusia di dalam realitas sosial masyarakat umumnya dan dalam konteks bangsa dan negara pada khususnya. Hukum sangat urgen adanya untuk mengatur kepentingan manusia baik sebagai makhluk individupersonal maupun sebagai makhluk sosial-kolektif. Sebagai makhluk personal dan sosial, manusia memiliki perasaan, pikiran, emosi dan kehendak yang layak untuk dilindungi dalam konteks kebersamaan yang ideal. Tanpa hukum, hak-hak dasar dan asasi manusia tak bisa dijamin keberlangsungannya secara wajar dan normal. Anarkisme akan hadir menggerogoti pribadi manusia.

Proses tumbuhnya hukum sebenarnya berlangsung secara dinamis dalam waktu yang sangat lama. Ditinjau dari sudut pandang sistem sosial, hukum sudah berlangsung sejak masyarakat komunal primitif hingga masyarakat modern sekarang ini (Prawironegoro, 2010). Hal itu menjadi jelas bahwa hukum, pada dasarnya, adalah suatu unsur atau anasir yang sangat penting eksistensinya bagi kelangsungan hidup manusia dalam kondisi-kondisi manusiawi. Hukum mengekspresikan dan memosisikan dirinya sebagai elemen substansial bagi komunitas atau kebersamaan manusia. Hukum berfungsi mengatur hubungan antarmanusia sebagai anggota masyarakat agar tercipta idealisme harmoni sosial. Tujuan pelaksanaan hukum yakni menciptakan kondisi masyarakat yang damai, teratur, selaras, dan berkeadilan.

Hukum, mengapa harus dilakukan? Dan bagaimana itu dilakukan? Dua pertanyaan ini menjadi sorotan klasik yang terus menjadi diskursus publik aktual pada berbagai level mulai dari praktisi hukum hingga kaum akademisi di berbagai belahan dunia ini. Umumnya diskusi meruncing dalam konfrontasinya dengan masalah keadilan praksis hukum. Lalu muncul masalah baru yakni: kalau begitu, hukuman yang dikatakan adil bagi manusia itu harus tampil dalam wajah atau paradigma seperti apa? Muncul banyak pendapat berbeda.

Hukuman yang adil akhirnya menjadi polemik panjang yang terus terjadi dalam jagad wacana hukum dan politik global. Perdebatan di tingkat filosofis pun tak kalah semarak. Banyak aliran pemikiran filsafat yang mempersoalkan, menyelidiki, merefleksikan dan mengkaji secara sistematis model ideal hukuman yang adil bagi manusia itu.

Ada banyak aliran pemikiran filsafat hukum yang mengupas masalah hukuman yang adil. Ada aliran retributivisme atau teori proporsionalitas yang dipelopori oleh filsuf Immanuel Kant dan Frieidrich Hegel. Retributivisme ini memiliki sebuah iman filosofis bahwa menghukum kejahatan adalah sebuah kewajiban moral yang harus tetap dilakukan demi mewujudkan sebuah "general will" atau kehendak umum masyarakat manusia. Retributivisme mengajarkan bahwa suatu hukuman dibenarkan karena merupakan retribusi terhadap pelanggaran atau kerugian yang sudah diakibatkan bagi orang lain. Tentang hukuman yang harus dilakukan pada seorang terhukum, ditegaskan juga oleh teori paduan antara retribusionisme dan utilitarisme (retributivisme teleologis) hasil racikan H.L.A Hart dan R.A Duff. Kedua pemikir hukum ini pun sepakat bahwa siapa pun yang melanggar hukum harus dihukum demi penegakan moralitas di dalam masyarakat. Pembahasan ini tidak akan melebar ke aliran lain, tetapi coba mengonsentrasikan telaahan pada perspektif hukum utilitarisme.

Utilitarisme memberikan suatu pesan filosofis mendasar bahwa semua tindakan dan keadaan harus ditentukan arah dan akibat-akibatnya ke masa depan, termasuk penerapan hukum kepada seseorang subjek terhukum. Salah satu tokoh utilitarian yang cukup populer dalam diskusi filsafat hukum khususnya terkait masalah hukuman yang adil atau keadilan hukuman yakni Jeremy Bentham. Bentham memiliki kontribusi pemikiran yang sangat signifikan terkait dengan masalah wajah atau 
paradigma hukuman yang adil. Bagaimana cerita hukum ini selanjutnya, ikuti kupasannya dalam uraian pembahasan. Kita akan lebih dahulu melihat tentang profil Jeremy Bentham.

\section{METODE PENELITIAN}

Peneliti menggunakan metode penelitian kualitatif (qualitative research methods) dalam merampungkan tulisan ini. Tulisan ini penulis kembangkan dengan menggunakan teknik kajian dokumentasi yakni berupa reserch dari buku-buku yang membahas topik-topik yang relevan dengan judul tulisan.

Penelitian terfokus pada dua konstruksi penting, yakni: keadilan hukum Jeremy Bentham dan pemikiran pokok Jeremy Bentham, dan coba membangun pikiran-pikiran pokok relevan yang bisa diterapkan dalam pelaksanaan hukum dunia dewasa ini. Refleksi kritis penulis sangat kental dikembangkan dalam merumuskan aspek-aspek relevan yang bisa menjadi masukan penting dalam konstelasi dunia hukum.

Teknik pengumpulan data yakni dengan membaca buku-buku sumber yang berkaitan dengan pemikiran hukum filsuf Jeremy Bentham. Setelah itu, penulis merumuskan gagasan inti pemikiran Bentham dan coba menarik nilai-nilai filosofis penting dari pemikiran filsuf ini bagi pelaksanaan hukuman yang diterapkan terhadap seorang terhukum yang melanggar hukum. Di sini penulis melakukan interpretasi dan analisis kritis atas pemikiran Bentham untuk menyingkapkan nilai-nilai kebenaran mendasar dari pemikiran filsuf tersohor Inggris ini untuk dunia hukum kontemporer.

Desain penelitian ini mencakup: proses pengumpulan data (referensi buku), analisis data dan interpretasi data, penulisan dan kesimpulan. Sedangkan pisau metodis utama yang diterapkan peneliti yakni menggunakan pendekatan hermeneuts-kritis, yakni melakukan penafsiran mendalam terhadap data (pemikiran) yang ada untuk menemukan nilai-nilai kebenaran mendasar yang relevan dengan topik pembahasan.

\section{HASIL DAN PEMBAHASAN}

Nama Jeremy Bentham sangat populer di kalangan masyarakat Inggris hingga sekarang ini. Ia lahir pada tanggal 15 Februari 1748 di London, Inggris. Ayah dan kakeknya berprofesi sebagai jaksa yang berkecimpung di bidang hukum. Latar belakang profesi ini membuat Bentham memiliki minat yang sangat tinggi terhadap masalah hukum sejak ia kecil. Ia lalu menempuh pendidikan hukum di Oxford dan memperoleh kualifikasi terakhir sebagai seorang barrister atau advokat di London. Hukum pula yang memberikan kontribusi besar mengharumkan namanya hingga memasuki abad ke21 ini.

Kondisi sosial politik yang didominasi oleh berbagai praktik ketidakadilan sosial di zamannya mendorong Bentham sebagai seorang mahasiswa hukum untuk peduli pada persoalan-persoalan yang berkaitan dengan moralitas publik. Ia terinspirasi untuk menulis banyak esai yang berkaitan dengan problem etika, politik, dan hukum yang memiliki relevansi praktis. Karena memiliki pemikiran yang luas, ia dipercayakan menjadi pemimpin kelompok filsuf radikal (philosophical radicals) yang menjadi ujung tombak (avant garde) dari gerakan reformasi liberal di Inggris. Gerakan ini banyak menyoroti masalah-masalah seputar pendidikan, hukum tentang aktivitas seksual, praktik korupsi dalam institusi-institusi publik, penyensoran dan pemenjaraan para pelaku kejahatan alias narapidana di Inggris. 
Bentham merupakan salah seorang filsuf besar aliran empirisme yang berpengaruh di bidang moral dan politik. Pemikiran filsafat hukum Bentham dipengaruhi oleh banyak filsuf sebelumnya. Gagasan penting Bentham tentang The Greates Happines Principle sangat kuat dipengaruhi oleh nama-nama filsuf seperti Protagoras, Epicurus, John Locke, David Hume, Montesquieu dan Thomas Hobbes. Sebagai filsuf pendiri utilitarisme Inggris, Bentham tumbuh menjadi seorang pemikir brilian yang menanamkan pengaruh kukuh bagi para filsuf pelanjut tradisi sesudahnya. Beberapa nama yang dapat disebutkan antara lain John Stuart Mill, Hendry Sidgwick, Michael Foucault, Peter Singer, John Austin, dan Robert Owen.

Di antara banyak filsuf yang mempengaruhi dinamika pemikiran Bentham, David Hume patut dicatat sebagai seorang filsuf penting yang sangat mempengaruhi pemikiran Bentham. Hume hidup antara tahun 1711-1776. Hume memiliki pemikiran kritis-rasional brilian yang meruntuhkan dasar teori ilmu alam waktu itu. Hume menegaskan bahwa sesuatu yang berguna haruslah dapat membawa kebahagiaan bagi individu manusia. Semua keputusan hukum harus menjamin kebahagiaan manusia baik sebagai individu maupun sosial.

Seorang pemikir biasanya menuangkan gagasannya dalam dokumen atau tulisan. Begitu juga halnya dengan Bentham yang senang menulis walau ia enggan untuk menerbitkan karya tulisnya. Ada satu hal yang unik dari sosok seorang Bentham. Sebelum satu tulisannya selesai, ia suka meninggalkan tulisan pertama yang belum tuntas digores dan langsung beralih untuk menggores tulisan lain lagi. Kalaupun ia menyelesaikan tulisannya itu, ia tidak suka mempublikasikannya ke publik. Namun banyak teman membantunya sehingga tulisan-tulisannya akhirnya bisa terekspos juga ke media massa.

Bentham sangat konsisten untuk memperjuangkan masalah-masalah hukum. Bentham bahkan merogoh koceknya sendiri dan mendirikan sebuah Westminister Review pada tahun 1824. Selama bertahun-tahun forum ini mempublikasikan ide-ide politik dan hukum Bentham bagi kalangan publik luas. Publik akhirnya bisa mengenal dan mengakui pemikiran-pemikiran Bentham. Banyak apresiasi positif dan konstruktif diberikan publik untuk menghargai forum ini. Suatu tanda bahwa pemikiranpemikiran Bentham mulai merasuki jagad wacana dan kesadaran orang bahkan berkembang meluas ke seantero dunia.

Sebagai seorang yang sangat rasional, Bentham membangun teori filsafat hukumnya di atas dasar individualisme dan utilitarianisme. Banyak filsuf menilai Bentham dengan multidimensi perspektif. Salah satunya, Bertrand Russel yang menilai bahwa Bentham membangun dasar filsafat hukumnya diatas dua prinsip pokok yakni: prinsip asosiasi (association principle) dan prinsip kebahagiaan terbesar (greatest happiness principle). Prinsip asosiasi merujuk pada hubungan antara ide dan bahasa, hubungan antara ide dengan ide. Sedangkan prinsip kebahagiaan terbesar merujuk pada kebaikan seorang individu. Dilihat dari latar belakang ide-idenya, kita dapat memahami bahwa pemikiran Bentham terinspirasi oleh kebangkitan humanisme zaman itu yang mengagungkan nilai instrinsik martabat kemanusiaan setiap individu-personal. Nilai humanisme tampak menjadi spirit dasar yang melekat erat dalam pemikiran hukum Bentham.

Sebagai pendukung teori kegunaan (utility theory), Bentham mengatakan bahwa tujuan hukum harus berguna bagi individu masyakat demi mencapai kebahagiaan sebesar-besarnya. Bentham dianggap sebagai bapak hukum Inggris karena pemikiran-pemikiran teoretisnya yang dinilai mendukung hukum yang berlaku di Inggris yakni common law.

Jeremy Bentham menutup usianya alias wafat pada tanggal 6 Juni 1832 dan mewariskan pemikiran hukum luar biasa yang terus dianuti banyak kalangan hukum dan politisi hingga dewasa ini walaupun tidak sedikit kritik yang menyerang pemikiran-pemikirannya. Selama hidupnya ia peduli pada kajian-kajian filosofis mendalam tentang paradigma keadilan hukum yang ideal bagi manusia. 


\section{Keadilan Hukum Jeremy Bentham}

Teori utilitarisme tentang hukuman tidak langsung terbentuk dalam waktu singkat. Ia bertumbuh dalam proses menjadi dalam waktu yang amat panjang. Teori utilirisme tentang hukuman berproses dalam sejarah yang panjang sejak filsuf Plato. Plato (427-347 SM) merupakan pemikir klasik Yunani yang juga memberikan pemikiran-pemikiran konstruktif penting terkait politik, hukum dan negara. Malahan dapat dikatakan bahwa gagasan Plato ini bisa menjadi cikal bakal kemunculan utilitarisme kelak.

Di dalam dialog Protagoras, Plato telah mendudukkan gagasan hukum berkaitan dengan praktik sebuah hukuman. Plato menulis bahwa dalam menghukum seseorang yang bersalah, kita tidak boleh mendasarkan hukuman atas fakta bahwa ia telah bertindak salah pada masa lampau atau menghukumnya dengan rasa balas dendam yang buta seperti seekor binatang, namun demi masa depan yaitu sebagai tindakan preventif bagi si terhukum dan orang-orang lain agar tidak lagi melakukan kesalahan (Ohoitimur: 1997, p. 25). Pandangan ini tidak hanya memerhatikan dimensi masa lampau dan masa sekarang dari praktik hukuman, tetapi lebih mementingkan dimensi masa depan hukuman pada si pelaku atau subjek pelanggar hukum. Banyak filsuf kontemporer lain di kemudian hari yang menganuti gagasan utilitaris Plato ini yakni T.L.S. Sprigge, S.I Benn dan J.J.C. Smart. Namun tulisantulisan mereka belum sempurna. Bentuk paling lengkap dan komprehensif dari teori utilitarisme tentang hukuman baru akan tereksplisitasi dalam tulisan-tulisan Jeremy Bentham yang diklaim sebagai bapak utilirisme Inggris.

Utilitarisme merupakan salah satu aliran filsafat yang memberikan kontribusi penting dalam aplikasi hukuman bagi manusia. Utilirarisme memiliki prinsip dasar filosofis atau pendirian sangat kukuh bahwa setiap hukuman yang adil bagi pelanggar hukum harus memerhatikan akibat-akibat selanjutnya. Teori ini sebetulnya merupakan bentuk terapan secara terbatas dari prinsip dasar etika utilitarisme yang menyatakan bahwa suatu tindakan dapat dibenarkan secara moral hanya sejauh konsekuensi-konsekuensinya baik untuk sebanyak mungkin orang (Ohoitimur:1997, p. 24). Di sini hukuman yang diberikan kepada seorang pelaku kejahatan harus mempertimbangkan juga sisi konsekuensi positifnya juga. Hukuman harus memerhatikan konsekuensi-konsekuensinya. Muncullah istilah konsekuensialisme yang diciptakan oleh Elizabeth Anscombe pada tahun 1957 (Jenny Teichman: 1998, p. 16).

Hukuman yang adil tidak boleh hanya melihat sisi negatifnya saja. Perspektif utilitarisme dapat diklaim sebagai pemikiran kontra terhadap praktik hukuman yang hanya melihat aspek negatifnya saja dari suatu hukuman yang diberikan pada subjek pelanggar hukum. Utilitarisme coba menyodorkan konsep alternatif. Utilitarisme menunjukkan suatu verfikasi etis (posivitisme hukum) dalam penerapan hukuman. Hukuman, sebagai suatu tindakan terhadap seorang penjahat, dapat dibenarkan secara moral bukan terutama karena si terhukum telah terbukti bersalah melawan hukum, melainkan karena hukuman itu mengandung konsekuensi-konsekuensi positif bagi si terhukum, korban, dan juga orang-orang lain dalam masyarakat (Ohoitimur: 1997, p. 24). Hukum harus memiliki relevansi positif-konstruktif bagi manusia. Jika tidak, hukuman tidak bermakna dan tidak berguna.

Teori Bentham tentang hukuman didasarkan atas prinsip kemanfaatan (Principle of Utility). Di dalam bukunya yang fenomenal (terbit tahun 1960) bertajuk Introduction to the Principles of Morals and Legislation, Bentham menggariskan arah dan visi hukum dari perspektif psikologis yang mendalam tentang prinsip utilitarisme. Bentham menulis: "Alam telah menempatkan manusia di bawah kekuasaan dua tuan, yaitu ketidaksenangan dan kesenangan. Apa yang harus kita lakukan dan apa yang akan kita perbuat, semuanya ditujukan dan ditetapkan dalam rangka keduanya. Standar baik dan buruk, serta mata rantai sebab dan akibat, juga terkait erat dengan kedua hal itu. Keduanya memandu kita dalam segala yang kita perbuat, dalam segala yang kita katakan dan pikirkan. Segala usaha yang dapat dilakukan untuk menolak ketaklukan kita terhadap dua kekuasaan itu, hanya akan 
membuktikan dan menegaskan kebenaran itu” (Bentham: 1960, p. 125). Menggunakan istilah utilitas atau kemanfaatan, Bentham menegaskan sebuah kebenaran faktual bahwa setiap orang cenderung untuk menghasilkan keuntungan, faedah, manfaat, kesenangan, kebaikan dan kebahagiaan bagi dirinya. Hal ini berarti setiap orang dalam tindakannya cenderung untuk menghindari diri dari situasi kemalangan, rasa sakit, kejahatan, ketidaksenangan, dan ketidakbahagiaan yang menganggu ketenangan dirinya.

Dari tulisan Bentham di atas, kita dapat menyimpulkan bahwa kebahagiaan setiap individu dalam hidup layak dilindungi, dipelihara dan dilestarikan. Dari sini muncul the Greatest Happiness Theory dari Bentham yang menegaskan bahwa tujuan tertinggi setiap orang dalam kehidupan ini yakni memperoleh kebahagiaan. Orang tidak mungkin tidak ingin bahagia dalam menghayati ziarah eksistensinya dalam realitas kehidupan ini. Kebahagiaan adalah tujuan tertinggi setiap pribadi manusia. Malah harus dikatakan kebahagiaan adalah kemungkinan ultima setiap manusia di planet bumi ini.

Kebahagiaan dan kesenangan yang diorbitkan Bentham tidak hanya merujuk pada konsekuensi-konsekuensi dari tindakan manusia secara subjektif (pribadi) tetapi juga berupa tindakan yang diputuskan oleh otoritas pemerintah atau pun kebijakan institusional hukum yang memiliki kewenangan mengatur dalam negara. Institusi dalam konteks ini tentu adalah lembaga hukum yang berkompeten memberikan vonis hukuman kepada seorang subjek terhukum (pengadilan). Tampak di sini bahwa ruang lingkup atau konstelasi pemikiran utilitarisme sangat luas baik itu mencakup dimensi individual maupun dimensi sosial. Dan karena itu, Bentham menetapkannya sebagai prinsip fundamental bagi hukum moralitas (Ohoitimur: 1997, p. 28). Berangkat dari hal ini kita sampai pada pertanyaan penting tentang bagaimana teori utilitas ini diterapkan pada hukuman untuk pribadi subjek terhukum.

Kalau setiap orang cenderung menghindari diri dari rasa sakit, kemalangan, kesedihan maka begitu pun dengan seorang terhukum yang hendak menerima hukuman. Seorang terhukum, secara manusiawi pastilah berusaha untuk mengelak dari hukuman yang merugikan dirinya. Namun kalau terpaksa seseorang harus dihukum atau menerima hukuman, maka pelaksanaan hukum tersebut harus menjanjikan bahwa hukuman dimaksud harus menghindarkan kerugian dan ketidaksenangan yang lebih besar. Hukuman yang tidak menjanjikan konsekuensi-konsekuensi yang lebih baik pada masa depan harus ditolak secara tegas. Hukuman yang baik harus menjamin keuntungan-keuntungan positif bagi pelaku. Hak seseorang untuk hidup bahagia dan terhindar dari hukuman lebih besar pada masa depan harus tetap jadi prioritas untuk dijaga dan dilindungi.

Teori utilitas Bentham mengatakan bahwa hukuman dapat dibenarkan jika pelaksanaannya mengkristalkan dua efek utama yakni: pertama, konsekuensi hukuman itu ialah mencegah agar di masa depan kejahatan terhukum tidak akan terulang lagi. Kedua, hukuman itu memberikan rasa puas bagi si korban maupun orang lain. Ciri khas hukuman ini bersifat preventif ke masa depan agar orang tidak lagi mengulangi perbuatannya dan pemenuhan rasa senang orang-orang yang terkait kasus hukum tersebut.

Dengan pencegahan (preventif), Bentham mensinyalir akan muncul tiga (3) bentuk efek yakni: pertama, hukuman yang diterima oleh si pelanggar hukum mengakibatkan bahwa ia kehilangan kemampuan untuk kelak mengulangi lagi kejahatan yang sama. Ini jika si terhukum dikurung dalam penjara seumur hidup, tangannya dipotong atau bahkan dieksekusi mati oleh vonis lembaga hukum formal.

Kedua, efek hukuman dapat pula berupa perubahan atau pembaharuan pada si terhukum. Ini mengandaikan hukuman memengaruhi dan membarui kecenderungan atau pun kebiasaan-kebiasaan yang tidak baik di dalam diri subjek terhukum, sehingga ia tidak ingin lagi melakukan kejahatan pada masa depan. Di sini mental orang dibarui sehingga ketika terbebas nanti, ia tidak lagi mau atau ingin 
untuk melakukan perbuatan melawan hukum. Ini mengandaikan si terhukum sudah mengalami transformasi diri sesudah menjalani tahapan proses hukum selama ia berada di dalam jeruji penjara.

Ketiga, efek jera dan penangkalan (deterrence). Hukuman harus mampu membuat jera subjek terhukum dan sekaligus menangkal kejahatan dari para penjahat potensial lain di dalam masyarakat. Hukuman ini membuat orang yang sudah bebas dari penjara kapok (jera) untuk berbuat melawan hukum lagi sekaligus memberi pesan bagi anggota masyarakat lain untuk tidak lagi melakukan kejahatan jenis baru di dalam realitas masyarakat. Wesley Cragg menilai bahwa fungsi penjeraan dari efek hukuman bisa dipahami sebagai suatu bentuk kontrol sosial (Cragg: 1992, p. 46). Sementara Philip Benn mengatakan maksud di balik penjeraan ialah mengancam orang-orang lain untuk kelak tidak lagi melakukan kejahatan (Bean: 1981, p. 46).

Selain tujuan primer hukuman di atas, Bentham juga menggariskan tujuan sekunder hukuman yang terkait erat dengan probabilitas atau kemungkinan pelanggaran hukum di masa depan. Dalam konteks ini Bentham bicara tentang kepuasan hukum. Kepuasan melalui hukuman dapat digapai dalam dua (2) bentuk yakni: pertama, kompensasi material dan kedua berupa pelampiasan atau pengekspresian rasa dendam. Walau jenis pertama sulit diterapkan pada semua kasus hukum, namun menurut Bentham, hukuman kompensasi material membawa banyak kesenangan bagi manusia. Uang merupakan kompensasi yang jitu terhadap banyak kejahatan (Bentham: 1962, p. 371). Bentham mengategorikan bahwa uang hanya mungkin untuk kasus pencurian dan perampokan, namun tidak bisa diterapkan untuk kasus delik kriminal seperti pembunuhan dan pemerkosaan. Hukuman sewajarnya pada si terhukum mengakibatkan rasa sakit pada subjek terhukum dan ini menjadi media penyaluran emosi negative si korban kejahatan dan keluarganya. Hukuman dapat memberikan rasa senang kepada si korban dan orang-orang lain yang terlibat dalam suatu kasus.

Bentham juga mengategorikan bentuk-bentuk hukuman kepada subjek terhukum yang dirunut dalam banyak daftar panjang tentang peraturan-peraturan. Di antara kompilasi banyak peraturan itu terdapat tiga hal paling utama yakni: pertama, hukuman harus tidak kurang berat dari apa yang diperlukan untuk mengimbangi kebaikan yang dihilangkan oleh tindakan kejahatan, dan hukuman yang terlalu ringan berpeluang tidak mencegah terulangnya jenis kejahatan yang sama. Kedua, semakin merugikan suatu kesalahan, semakin berat pula hukuman yang harus dijatuhkan atas si terhukum atau pelakunya. Dan ketiga, hukuman tidak harus lebih berat daripada apa yang perlu untuk mencapai tujuan-tujuannya pada masa depan. Inilah garis-garis pokok pemikiran Bentham tentang asas kemanfaatan (utilitas) di balik hukuman yang diterapkan pada seorang terhukum. Tentang pemikiran Bentham ini, J. S. Mill pernah menulis bahwa Bentham telah menciptakan suatu teori yang hampir sempurna tentang pembenaran hukuman legal (Ohoitimur: 1997, p. 33).

\section{Relevansi Pemikiran Bentham bagi Praktik Hukum Kontemporer}

Bentham adalah seorang filsuf yang mendukung paham utilitarisme. Banyak pemikirannya masih diaplikasikan dalam praksis hukum negara-negara modern hingga kini walaupun ada kritikan pada teori-teori hukumnya. Perspektif utilitas yang dikembangkan Bentham pada prinsipnya merefleksikan pokok pikiran penting tentang nilai martabat manusia sebagai subjek yang bernilai inse. Bentham sangat menjunjung tinggi martabat manusia dan ia coba melindungi martabat itu melalui pandangan-pandangan filsafat utilitasnya.

Bentham punya suatu proyeksi visioner yang jauh ke depan untuk setiap subjek manusia yang terhukum. Substansi visi itu yakni bahwa manusia mempunyai kemungkinan untuk hidup lebih baik atau lebih bahagia di masa depan. Karenanya, praktik hukum harus diusahakan untuk tetap menghargai dan menempatkan subjek terhukum sebagai sosok yang wajib dihargai meskipun ia melanggar hukum dalam kehidupan bersama (berbangsa dan bernegara). 
Pelaksanaan hukuman kepada subjek terhukum harus dipahami sebagai instrumen atau sarana pembelajaran bagi yang bersangkutan agar ia bisa mengubah dirinya ke arah yang lebih baik di masa depan. Sebuah transformasi diri diharapkan terjadi dalam diri terhukum. Hukuman terhadap subjek yang melanggar hukum dilaksanakan bukan pertama-tama atas dasar balas dendam, melainkan harus dipahami dalam konteks kebaikan subjek terhukum itu sendiri di masa depan. Artinya walaupun subjek terhukum sudah melanggar hukum, ia toh tak boleh dipandang bahwa ia sudah selesai sebagai manusia. Subjek terhukum tetaplah masih sosok manusia yang senantiasa berproses dalam perjalanan dinamika waktu menuju martabat pribadinya yang lebih ideal di masa depan. Subjek terhukum masih tetap memiliki peluang untuk mewujudkan kemungkinan ultimnya di masa depan.

Logika yang harus ada di balik jagad wacana para pengambil keputusan hukum adalah tetap menghargai manusia subjek pelanggar hukum dan merasa optimistis bahwa subjek terhukum masih dapat berpeluang besar kembali menjadi orang baik di masa depan. Perspektif ini mengandung amanah bahwa subjek terhukum pantas dilindungi haknya juga sebagai manusia. Sehingga dalam praksis hukuman yang diberikan, tidak semata-mata sebagai ekspresi sisi negatif dan meredusirnya pada sebuah aksi balas dendam semata-mata.

Walau tidak dapat dipungkiri bahwa hukuman yang dijatuhkan itu sebagai katalisator atau pengalih rasa sakit hati para korban atau keluarga korban, kita harus tetap sadar bahwa kita berhadapan dengan sosok pribadi manusia yang bernilai intrinsik. Kita bukan berhadapan dengan barang atau objek abiotis ataupun makhluk infrahuman non-manusiawi. Kesadaran etis akan pentingnya marbatat manusia harus ada dalam pelaksanaan hukuman bagi subjek pelanggar hukum. Hanya dengan ini hukuman terhadap si terhukum membawa nilai utilitas (manfaat) bagi subjek terhukum. Nilai kemanusiaan kita pun terlindungi dari aksi buta balas dendam yang merendahkan kemanusiaan kita sendiri. Perspektif ini pun dapat mengeksplisitasikan praktik hukum yang adil dalam hidup berbangsa dan bernegara. Apapun kesalahan yang dilakukan oleh subjek yang melanggar hukum, kemanusiaan wajib dibela, dilindungi dan dilanggengkan.

Dalam diskursus filsafat, etika adalah cabang yang menyelidiki perbuatan-perbuatan yang dikategorikan baik dalam ranah praksis kehidupan manusia. Sebagai filsuf, Bentham pun menyisipkan pandangan-pandangan hukumnya yang mengedepankan nilai-nilai etis-moral di dalamnya. Etika dan moralitas dijadikan pegangan dasar dalam mengorbitkan pandangan-pandangannya terkait paradigma hukuman yang adil itu.

Dalam konteks hukuman yang adil, perlu diperhatikan maksud baik di balik penerapan hukuman bagi subjek terhukum. Bahwa, yang penting adalah membersihkan motivasi para penegak hukum dalam menghukum seorang subjek terhukum. Hukuman yang adil bukan berarti hukuman yang bebas dari kandungan nilai moral-etis di dalamnya. Hukuman yang adil walaupun untuk menghukum pelanggaran yang dilakukan oleh subjek terhukum, harus dilaksanakan dalam standar etis-moral yang baik juga. Bahwa, pelaksanaan hukuman kepada subjek terhukum harus merefleksikan etika dan maksud baik di dalamnya.

Setiap hakim yang menjatuhkan vonis perkara di pengadilan haruslah memutuskan sanksi hukum kepada subjek terhukum atas dasar etika. Keputusan hakim di pengadilan bukan pertama-tama untuk menghukum subjek pelanggar hukum, namun untuk melindungi moralitas dan nilai-nilai etis dalam realitas kehidupan. Dengan ini seorang hakim terhindar dari kesempitan perspektif di mana hanya menghukum seseorang tanpa kesadaran moral-etis didalamnya. Jika seorang hakim memutuskan hukuman tanpa kesadaran moral-etis, keputusan itu kurang adil bagi subjek terhukum. Keputusan hukum harus dilandasi oleh nilai etika dan maksud baik bagi kebaikan subjek terhukum di masa depan. 
Landasan etis-moral harus dipahami oleh para eksekutor hukum (hakim) secara konsisten. Artinya mereka menjalankan kekuasaan memvonis perkara subjek terhukum bukan hanya untuk mengikuti tulisan-tulisan dokumentatif yang sudah dirunutkan secara rapih di dalam pasal-pasal hukum yang ada. Namun yang penting adalah makna di balik pasal-pasal delik itu. Menjatuhkan vonis hanya terfokus pada pasal-pasal hukum tanpa kesadaran etis-moral di dalamnya sama artinya dengan inkonsistensi dogmatis yang irelevan dan tindakan dehuman atas manusia. Dan para pengambil hukuman tidak lebih dari sekedar eksekutor yang miskin nilai etis-moral. Karena itu penting ditanamkan suatu kesadaran etis mendasar di dalam diri para hakim atau siapapun eksekutor hukum yang menjalankan mandat kekuasaan untuk menghukum subjek terhukum atau pribadi yang melanggar hukum.

Penjara atau lembaga pemasyarakatan sebagai tempat menjalankan hukuman, dilukiskan sebagai tempat pendidikan moral, yaitu tempat di mana refleksi-refleksi moral dan spiritual diadakan serta "penebusan dosa" terjadi (Ohoitimur: 1997, p. 40). Di dalam penjara subjek terhukum mengalami proses purifikasi (pemurnian) moral. Itu artinya, di penjara harus diupayakan subjek terhukum mendapatkan siraman rohani dan edukasi moral yang cukup baik, agar kelak ia dapat menjadi “orang baik" kembali di dalam masyarakat. Hal ini berdasarkan asumsi bahwa subjek terhukum telah melalaikan kewajiban moral menjadi orang baik di dalam masyarakat dengan melanggar hukum. Karena itu penjara menjadi tempat rehabilitasi moral kembali.

Sejauh ini istilah penjara dapat dikatakan menjalankan fungsinya sesuai dengan teori rehabilitasi kaum utilitas. Jika demikian, tentunya penjara-penjara di setiap negara harus menjalankan proses hukuman secara manusiawi demi keadilan pada subjek terhukum sendiri yang berhak diperlakukan sebagai manusia. Perlu diterapkan konseling-konseling konstruktif atau pun terapi penyembuhan, pendalaman spiritual dan kegiatan-kegiatan sosial yang menegakkan kembali martabat kemanusiaan mereka yang telah jatuh dalam perbuatan pelanggaran hukum. Hakim dan penjara harus tetap menerapkan prinsip-prinsip etis-moral terhadap para pelanggar hukum. Ini penting untuk mencegah munculnya tindakan-tindakan agresif di penjara yang menciptakan trauma berkelanjutan terhadap para narapidana.

\section{Dimensi Utilitas Hukuman}

Makna kunci di dalam istilah atau kosakata utilitas Bentham yakni kemanfaatan. Di dalam menghukum subjek terhukum, lembaga penegak hukum atau apapun otoritas yang berwenang tentu harus mempertimbangkan manfaat hukuman bagi subjek pelanggar hukum. Apakah hukuman itu bermanfaat positif bagi subjek pelanggar hukum ke depannya, di sini perlu diperhatikan mekanisme pelaksanaan hukuman agar sesuai dengan tujuan hukuman itu sendiri. Jika hukuman itu tidak bermanfaat, hukuman itu tidak adil. Hukuman akan menjadi sebuah praktik formalistis yang kehilangan relevansi nilai guna.

Hukuman yang bermanfaat adalah hukuman yang membawa makna dan nilai positif bagi subjek terhukum, masyarakat publik dan para penjahat potensial di dalam masyarakat. Hukuman bermanfaat untuk pelaku pelanggar hukum yakni membuat jera pelaku, dengan tujuan untuk menciptakan masa depan subjek terhukum lebih baik. Setiap bentuk hukuman yang tidak menjamin masa depan lebih baik bagi subjek terhukum, layak dikritisir malah ditolak secara tegas. Di sini kita bicara tentang kebahagiaan bagi subjek terhukum sendiri.

Jika hak setiap manusia yakni ingin hidup bahagia dalam kehidupan ini penting, maka hukuman perlu diupayakan agar memastikan hidup subjek terhukum dalam kondisi bahagia dimasa depan. Hukuman yang dijalankan oleh subjek terhukum, membuat hidupnya kurang bahagia. Kebahagiaan subjek terhukum yakni bebas dari hukuman. Kalau menjalankan hukuman, itu artinya kebahagiaan subjek terhukum terpangkas, terpotong, dan terpasung. Untuk itu subjek terhukum akan merasa kurang bahagia. Kebahagiaan mengandaikan kondisi kebebasan. 
Hukuman yang dijalankan harus mengarahkan subjek terhukum pada kondisi masa depan sesudah bebas nanti. Bahwa, ia tidak boleh lagi melanggar hukum. Ia harus sungguh-sungguh menghayati manfaat positif dari hukuman yang dijalankannya agar kelak ketika bebas ia hanya melakukan hal-hal yang menyenangkan, hal-hal yang baik, hal-hal positif yang mengondisikan hidupnya dalam kondisi bahagia. Mampukah hukuman ataupun penjara menjamin masa depan bahagia bagi subjek terhukum?

Satu pertanyaan yang sering mengusik nurani kita yakni mengapa kesadaran akan dimensi kebahagiaan ini kurang disadari oleh banyak penegak hukum di dunia. Mengapa justru seorang subjek terhukum bisa melakukan kejahatan kedua lagi setelah bebas. Masih saja ada subjek terhukum yang justru senang keluar-masuk penjara beberapa kali. Apakah orang-orang seperti ini merasa senang berada di penjara, apakah mereka senang kebebasan mereka dipangkas oleh penjara. Kalau seperti ini jadinya, teori Bentham tak menyentuh subjek terhukum seperti ini. Namun perlu diketahui, Bentham justru membidik masa depan yang membuat subjek terhukum bahagia karena ia akan berusaha untuk tidak masuk penjara lagi dengan mulai melakukan tindakan-tindakan yang baik untuk memperoleh kebahagiaan sejati di tengah masyarakat. Jadi, bukan memperoleh kebahagiaan dengan masuk-keluar penjara beberapa kali.

Penjara memang belum tentu menjamin bahwa seseorang yang sudah pernah melakukan kejahatan dijamin tidak akan masuk lagi. Akan tetapi, hal ini bukan masalah. Yang penting adalah penjara harus tetap pada visi dasar mengikhtiarkan hal-hal berguna bagi subjek hukum, terlepas dari pilihan-pilihan bebas subjek terhukum sesudah keluar dari penjara. Penjara harus tetap berada pada visi utama: melakukan pembelaan mendasar terhadap sifat utilitas hukuman. Hanya dengan ini penjara tetap memiliki nilai guna yang relevan bagi para subjek pelanggar hukum.

\section{SIMPULAN}

Bagaimana suatu praktik hukuman dikatakan adil dan dapat dibenarkan? Pertanyaan ini menjadi pertanyaan kritis yang telah digaungkan terus-menerus sepanjang zaman di semua negara dalam masyarakat kontemporer. Alasannya, karena praktik hukuman yang sungguh-sungguh adil bagi manusia masih harus terus diperjuangkan dalam praktik hukuman berbagai bangsa di dunia ini. Sering kali karena kekeliruan manusiawi, para eksekutor hukum melalaikan mekanisme praktik hukuman yang adil pada subjek terhukum. Akibatnya, pratik hukuman bukan malah mendatangkan manfaat, melainkan justru mendatangkan risiko lebih buruk bagi subjek terhukum. Sebuah kesadaran baru dalam momentum kekinian harus tetap diperjuangkan dan dihayati oleh para penegak hukum negara. Setiap penegak hukum harus selalu menyadari pentingnya hukuman yang mencerminkan nilai-nilai humanis, etis-moral, dan nilai kegunaan atau manfaat.

Kita bisa bercermin atau mengambil inspirasi dari pandangan kaum utilitaris khususnya pemikiran Jeremy Bentham yang sudah dikaji dalam tulisan ini. Bentham mengembangkan sebuah teori yang relevan dan tetap bermakna sepanjang masa tentang praktik hukuman yang adil bagi seorang subjek terhukum. Ia menggariskan pokok-pokok pemikiran tentang hukuman yang adil dari perspektif utilitas atau prinsip kemanfaatan. Setiap bentuk hukuman yang adil adalah hukuman yang mendatangkan manfaat sebesar-besarnya bagi subjek pelanggar hukum itu sendiri pada masa depan.

Dasar etis teori hukum Bentham menitikberatkan pada unsur psiko-humanis, dimensi etismoral, dan dimensi utilitas bagi subjek terhukum. Bentham menegaskan bahwa hukuman yang tidak mengindahkan ketiga hal ini, patut ditolak karena tidak adil dan tidak bisa dibenarkan secara logisempiris. Oleh karena itu, hukuman yang adil bisa direalisasikan hanya jika para eksekutor hukum memerhatikan dimensi humanisme, dimensi etis-moral, dan dimensi utilitas dalam proses hukuman 
terhadap subjek pelanggar hukum. Hanya dengan ini hukuman dikatakan adil. Di luar ketiga hal ini, hukuman dikatakan tidak adil, dan karena itu, tak layak diterima oleh seorang subjek terhukum. Konsekuensi lanjutnya, hukuman yang adil menjadi kontradiksi menjadi hukuman yang tidak adil.

\section{DAFTAR PUSTAKA}

Bean, P. (1981). Punishment: A Philosophical and Criminological Inquiry. Oxford: Martin Robertson.

Bentham, J. (1960). Introduction to the Principles of Morals and Legislation. Oxford: Basil Blackwell. . (1962). Principles of Penal Law. New York: Russel and Russel.

Bertens, K. (2001). Ringkasan Sejarah Filsafat. Yogyakarta: Kanisius.

Cragg, W. (1992). The Practical Punishment: Towards a Theory of Restorative Justice. London, New York: Routledge.

Holyer, R. (1994). Capital Punishment and the Sancrity of Life. International Philosophical Quarterly, Vol. XXXIV, No. 4 Issue No. 136.

Ohoitimur, Y. (1997). Teori Etika tentang Hukuman Legal. Jakarta: Gramedia.

Plamenatz, J. (1966). English Utilitarians. Oxford: Basil Blackwell

Prawironegoro, D. (2010). Filsafat Ilmu. Jakarta: Nusantara Consulting.

Teichmann, J. (1998). Etika Sosial. Yogyakarta: Kanisius.

Wood, A. (1990). Hegel's Ethical Thought. Cambridge: Cambridge University Press. 